\title{
Professor Sadik Kakaç on His 85th Birthday
}

\author{
Mohamed M. Awad ${ }^{1} \cdot$ Yildiz Bayazitoglu ${ }^{2} \cdot$ Adrian Bejan $^{3} \cdot$ Andrea Luke $^{4} \cdot$ Franz Mayinger $^{5}$. \\ Anchasa Pramuanjaroenkij ${ }^{6}$. Leonard L. Vasiliev ${ }^{7}$
}

Received: 16 March 2018 / Accepted: 28 August 2018 / Published online: 15 September 2018

(C) Springer-Verlag GmbH Germany, part of Springer Nature 2018

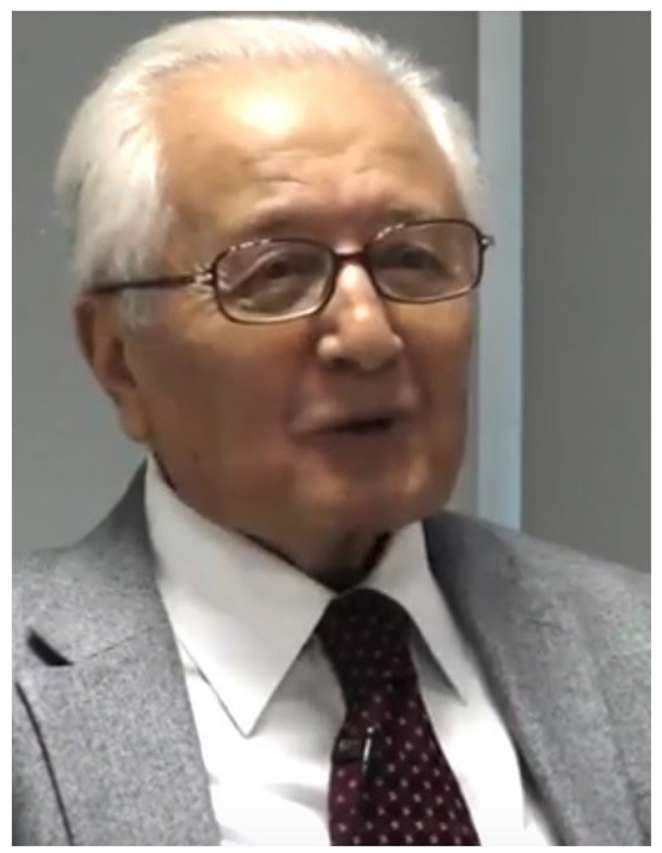

Mohamed M. Awad

m_m_awad@mans.edu.eg

Yildiz Bayazitoglu

bayaz@rice.edu

Adrian Bejan

abejan@duke.edu

Andrea Luke

luke@uni-kassel.de

Franz Mayinger

mayinger@td.mw.tum.de; franz-mayinger@t-online.de

Anchasa Pramuanjaroenkij

anchasa@gmail.com

Leonard L. Vasiliev

leonard_vasiliev@rambler.ru
Professor Sadik Kakaç is one of the well-known names in the field of heat transfer, heat exchangers, and multiphase flow and well respected among his colleagues in the heat transfer, heat exchangers, and multiphase flow community all over the world. He was born on the $1^{\text {st }}$ October 1932, in Çorum, Turkey. He studied engineering at the Technical University of Istanbul (ITU) and received his degree of Dipl.-Ing from the Department of Mechanical Engineering at the Technical University of Istanbul (ITU) in 1955. Within the period of 1955-1958, Professor Sadik Kakaç joined the Heat Technique chair to start his professional life as a research/ teaching assistant in the Department of Mechanical Engineering at the Technical University of Istanbul (ITU). Then, he studied at the Massachusetts Institute of Technology (MIT) after receiving an Eisenhower Fellowship to study peaceful use of atomic energy. He earned master's degrees in mechanical engineering and nuclear engineering in 1959 and 1960, respectively, from the Massachusetts Institute of Technology (MIT). Within the period of 1963-1965, he did his Ph. D. at the Victoria University of Manchester, UK after receiving a scholarship from the British government in 1963.

1 Mechanical Power Engineering Department, Faculty of Engineering, Mansoura University, Mansoura 35516, Egypt

2 Department of Mechanical Engineering and Materials Science, Rice University, 6100 Main Street, MS 321, Houston, TX 77005-1892, USA

3 Department of Mechanical Engineering and Materials Science, Duke University, Durham, NC 27708-0300, USA

4 Technical Thermodynamics, University of Kassel, Kurt-Wolters Str. 3, 34125 Kassel, Germany

5 Lehrstuhl für Thermodynamik, Technische Universität München, 85747 Garching, Germany

6 Faculty of Science and Engineering, Kasetsart University, Chalermphrakiat Sakon Nakhon Province Campus, Chatuchak, Bangkok, Thailand

7 Luikov Heat \& Mass Transfer Institute, National Academy of Sciences Minsk Belarus, 15, P. Brovka Str., 220072 Minsk, Belarus 
After returning back from the Massachusetts Institute of Technology (MIT), Professor Sadik Kakaç began his academic life as an instructor 1960 in the Department of Mechanical Engineering at the Middle East Technical University (METU), Ankara, Turkey. After obtaining his Ph. D. in 1965, he became Associate Professor in the Department of Mechanical Engineering at the Middle East Technical University (METU), Ankara, Turkey. Professor Sadik Kakaç became Professor in the Department of Mechanical Engineering at the Middle East Technical University (METU), Ankara, Turkey in 1970. During that period, he helped in building the Mechanical Engineering Department and the heat transfer lab at the Middle East Technical University (METU), Ankara, Turkey.

Professor Sadik Kakaç held various governmental and research positions in Turkey. For example, he was elected as a member of the Turkish Scientific and Technological Research Council (TUBITAK) within the period of 1972-1980. He was appointed as the Secretary General of the Turkish Atomic Energy Commission within the period of 1978-1980. He was representing Turkey in a number of scientific endeavors around the globe as a member of NATO Science Committee during 1979/1980, the OECD NEA Steering Committee during 1978/1980, the Cento Scientific Coordinating Board during 1972/1974. Within the period of 1976-1978, Professor Sadik Kakaç served as the Chairman of the Mechanical Engineering Department at the Middle East Technical University (METU), Ankara, Turkey.

In 1980, Professor Sadik Kakaç was a visiting professor in the department of mechanical engineering at the University of Miami in Coral Gables, Florida. He was appointed as a full professor of mechanical engineering with tenure in 1982. Within the period of 1990-1998, he served as chairman of the department. He retired from the University of Miami in 2008 and since then he has been a Professor at TOBB University of Economics and Technology, in Ankara, Turkey. He has been frequently invited as a lecturer and speaker by different institutions in US, Europe, China, Malaysia, Singapore, Brazil, Bulgaria and other countries. He organized short courses on Heat Exchangers thermal design in Taiwan, Singapore, Thailand, France, Brazil, and Turkey.

During his work at Department of Mechanical Engineering, Middle East Technical University, Ankara, Turkey, Department of Mechanical Engineering, University of Miami, Florida, USA as well as TOBB University of Economics and Technology, Ankara, Turkey, Professor Sadik Kakaç published over 300 reports and papers as well as many books on heat and mass transfer, heat exchangers, and multiphase flow like Refs. [1-10]. His review paper in 2009 on "Convective Heat Transfer Enhancement With Nanofluids" in the International Journal of Heat and Mass Transfer [11] has more than 1200 citation.
Professor Sadik Kakaç is the Recipient of several international awards like Alexander von Humboldt Senior Distinguished US Scientist Award in 1989 for his outstanding contributions on heat transfer and two-phase flow. He received Science Award from the Association of Turkish-American Scientists in 1994. He received the American Society of Mechanical Engineers (ASME) Heat Transfer Memorial Award in 1997 due to his contributions to research and education through his research work and books. He received distinguished service awards from the Middle East Technical University (METU) in 1998, and from the Turkish Scientific and Technical Research Council (TUBITAK) in 2000.

The ASME Heat Transfer Division (HTD) celebrates its 75th anniversary during ASME 2013 Summer Heat Transfer Conference (HTC2013), Minneapolis Minnesota, July 14-19, 2013 [12]. Professor Sadik Kakaç received HTD's 75th Anniversary Award at HTC2013. Few months later, professor Sadik Kakaç awarded ASME Honorary Membership at the ASME 2013 International Mechanical Engineering Congress \& Exposition (IMECE2013), San Diego, CA, November 15-21, 2013 for seminal and pioneering achievements in transient two-phase flows, fuel cells and micro/nano heat transfer research and engineering; and for sustained contributions to education as an organizer of conferences and author of well-known textbooks on heat transfer and heat exchangers "https://www.asme.org/about-asme/getinvolved/honors-awards/press-releases/sadik-kakacawarded-honorary-membership, https://www.asme.org/ engineering-topics/media/heat-transfer/video-sadik-kakac2013-honorary-membership".

Professor Sadik Kakaç is the first Turkish scientist who received 2014 Luikov Medal awarded to scientists each two years by the International Centre for Heat and Mass Transfer (ICHMT) "http://www.ichmt.org/page/50/lmedal". This Medal has been awarded to scientists who have made a significant contribution to the science of development of international cooperation in this area and has been given to scientists from various countries throughout the world since 1979.

Deemed deserving of the 2014 Luikov Medal by ICHMT for his significant contributions to the heat and mass transfer science and developing the international cooperation in this field, Professor Sadik Kakaç not only has several achievements in this field and books, which are used in education throughout the world, but he has formulated an important parameter used by researchers in the fluids mechanism that has been named the 'Kakaç number' [13]. The Kakaç number is defined as follows:

$$
\text { Kakaç number }=\frac{P D}{\mu_{l} h_{f g}^{1 / 2}}
$$


Where $\mathrm{P}$ is pressure $(\mathrm{Pa}), \mathrm{D}$ is outside diameter of the tube (m), $\mu_{1}$ is liquid dynamic viscosity $(\mathrm{kg} / \mathrm{ms})$, and $\mathrm{h}_{\mathrm{fg}}$ is latent heat of vaporization $(\mathrm{J} / \mathrm{kg})$.

The Kakaç number gives the combined effect of the bubble growth dynamics with the thermal influences in the thermal boundary layer adjacent to the wall. Including this dimensionless number led to a correlation with better accuracy [13].

Professor Sadik Kakaç received the Doctor Honoris Causae from the University of Ovidius, Romania in 1998, the University of Reims, France in 1999, and Odessa State Academy of Refrigeration in 2007. He is a foreign member of the Academy of Sciences of the Republic of Bashkortostan of Russian Federation in 1998, and a member of the Turkish Academy of Sciences in 1999. He is honorary Professor of Shanghai Institute of Electrical Power, China in 1986, Xi'an Jiatong University, China in 1988, the Engineering College at the Ghandi Institute of Technology and Management, India in 1992. He is a Fellow member of ASME.

He served as a member of the Max Jakob award committee during 1999/2005 and the committee chairman in 2005. He is a member of the Scientific Council, and the Executive Committee, and Fellow of the International Centre of Heat and Mass Transfer (ICHMT). During a difficult period to the existence of ICHMT, he was very active to transfer the centre to Turkey and to find financial support from TUBITAK for its functioning throughout these years.

He has started well known NATO Advanced Study Institutes on different topics of thermal and fluid sciences in 1976. Most of these workshops have resulted in archival books, which present the background and present status in the areas considered.

On the occasion of his $85^{\text {th }}$ birthday, on behalf of his students, colleagues and friends all over the world, we wish Professor Sadik Kakaç a very happy birthday and a continuous active life in good health and happiness!
Publisher's Note Springer Nature remains neutral with regard to jurisdictional claims in published maps and institutional affiliations.

\section{References}

1. Kakaç S, Shah RK, Bergles AE (1983) Low Reynolds number flow heat exchangers. Hemisphere Publishing Corporation, Washington DC, pp 15-19

2. Kakaç S, Shah RK, Aung W (1987) Handbook of single-phase convective heat transfer. Wiley, New York

3. Kakaç S (1991) Boilers, evaporators, and condensers. Wiley, New York

4. Kakaç S, Bergles AE, Mayinger F, Yüncü H (eds) (1999) Heat transfer enhancement of heat exchangers. (NATO ASI Series E Vol 355). Kluwer. https://doi.org/10.1007/978-94-015-9159-1

5. Yener Y, Kakaç S (2008) Heat conduction. Taylor \& Francis Group, New York

6. Kakaç S, Pramuanjaroenkij A, Vasiliev LL (eds) (2008) Mini-micro fuel cells: Fundamentals and applications. Springer. https://doi.org/ 10.1007/978-1-4020-8295-5

7. Kakaç S, Bergles AE, Fernandes EO (2012) Two-phase flow heat exchangers: Thermal-hydraulic fundamentals and design. Springer. https://doi.org/10.1007/978-94-009-2790-2

8. Kakaç S, Liu H, Pramuanjaroenkij A (2012) Heat exchangers: Selection, rating, and thermal design. CRC Press, Boca Raton

9. Kakaç S, Yener Y, Pramuanjaroenkij A (2013) Convective heat transfer. CRC Press, Boca Raton

10. Vasiliev LL, Kakaç S (2013) Heat pipes and solid sorption transformations: Fundamentals and practical applications. CRC Press, New York, p 411-464

11. Kakaç S, Pramuanjaroenkij A (2009) Review of convective heat transfer enhancement with nanofluids. Int J Heat Mass Transf 52(13):3187-3196 http://www.sciencedirect.com/science/article/ pii/S0017931009001069

12. Marner WJ (2013) 75 years of progress: A history of the ASME heat transfer division. ASME J Heat Transf 135(6) Article No. (061001) http://heattransfer.asmedigitalcollection.asme.org/article. aspx?articleid $=1688843$

13. Sarma PK, Srinivas V, Sharma KV, Subrahmanyam T, Kakaç S (2008) A correlation to predict heat transfer coefficient in nucleate boiling on cylindrical heating elements. Int J Therm Sci 47(3):347-354 